Иньков М.Е.

\title{
Результаты педагогического эксперимента по развитию профессиональной педагогической компетентности работников образования*
}

Одним из направлений исследований научной школы концептуальной педагогической диагностики является разработка критериев и инструментария диагностирования профессиональной педагогической компетентности.

Нами на основе концепции педагогического профессионализма Н.В.Кузьминой была предложена модифицированная пятикомпонентная моделью оценки интегральной профессиональной компетентности педагога и проведен методологический эксперимент для выявления соотношения выделенных факторовкомпонентов. Предварительно, до начала эксперимента, на основе экспертной оценки содержательной значимости критериальных показателей (3 доктора наук и 2 кандидата наук) определены весовые коэффициенты, которые указаны в скобках. Анализировались соотношения следующих составляющих интегральной характеристики педагогического профессионализма:

- социальная и профессиональная компетентность в области преподаваемой дисциплины $(0,21)$;

- методическая компетентность в области способов формирования знаний, умений учащихся $(0,19)$;

- социально-психологическая компетентность в области процессов общения $(0,17)$;

- дифференциально-психологическая компетентность в области мотивов, способностей учащихся $(0,20)$;

- аутопсихологическая компетентность в области достоинств и недостатков собственной деятельности личности $(0,23)$.

Для этого в 2006 г. в Ростовском областном ИПК и ПРО были сформированы экспериментальная (103 чел.) и контрольная (102 чел.) группы, обладающие репрезентативными свойствами. Обе группы были еще на стадии подбора практически уравнены как по половозрастному признаку, так и по исходному уровню ранее полученных оценок профессиональных категорий - второй, первой, высшей. В результате квалиметрического анкетирования с помощью методики корреляционных пар критериальных показателей, педагогической диагностики на констатирующем этапе педагогического эксперимента установлена степень выраженности различных видов компетентности педагогов.

* Материалыпредставлены научным руководителем-проректором по научно-методической работе РОИПКиПРО, зав. кафедрой информационных технологий, доктором педагогических наук, профессором Сафонцевым С.А. 
Все компоненты модели - виды профессиональной компетентности педагогов совершенствовалась на формирующем этапе эксперимента в процессе реализации теоретической модели исследования (Таблица 1).

Таблица 1

Степень выраженности различных видов компетентности

\begin{tabular}{|l|c|c|c|c|}
\hline \multirow{2}{*}{ Вид компетентности } & \multicolumn{2}{|c|}{$\begin{array}{c}\text { Экспериментальная } \\
\text { группа }\end{array}$} & \multicolumn{2}{|c|}{$\begin{array}{c}\text { Контрольная } \\
\text { группа }\end{array}$} \\
\cline { 2 - 5 } & $\begin{array}{c}\text { Входной } \\
\text { контроль }\end{array}$ & $\begin{array}{c}\text { Итоговый } \\
\text { контроль }\end{array}$ & $\begin{array}{c}\text { Входной } \\
\text { контроль }\end{array}$ & $\begin{array}{c}\text { Итоговый } \\
\text { контроль }\end{array}$ \\
\hline Специальная и профессиональная & 62 & 78 & 61 & 64 \\
\hline Методическая & 58 & 76 & 58 & 58 \\
\hline Социально-психологическая & 52 & 60 & 54 & 58 \\
\hline Дифференциально-психологическая & 55 & 86 & 54 & 54 \\
\hline Аутопсихологическая & 67 & 82 & 65 & 75 \\
\hline
\end{tabular}

На стадии входного контроля в констатирующем эксперименте, нет существенных различий между экспериментальной и контрольной группами (а по уровню методической компетенции они полностью совпадают).

Система работы в формирующем эксперименте, как показывают данные Таблицы 1, в экспериментальной группе привела к существенному повышению показателей по всем компонентам, но в наибольшей степени по дифференциальнопсихологическому (21 \%) и в наименьшей - по социально-психологическому (8\%). Все различия статистически значимы, и они вполне отражают соотношение усилий, направленных на развитие этих компонентов - видов компетенций в ходе реализации содержательной части программы эксперимента. Обращает внимание тот факт, что и в контрольной группе по трем существенным критериям из пяти произошли существенные позитивные сдвиги (в большей степени - по аутопсихологической компетенции, несколько в меньшей - по социальной и профессиональной компетенции и по социально-психологической). Это можно, на наш взгляд, отнести за счет позитивного влияния общей программы повышения квалификации, участие в реализации которой принимают высококомпетентные специалисты по педагогике, психологии и методике из ведущих вузов Ростова и Таганрога.

Расхождения медиан [2] количественныхпоказателей различных видов компетентности участников экспериментальной и контрольных групп приведены на Диаграмме 1.

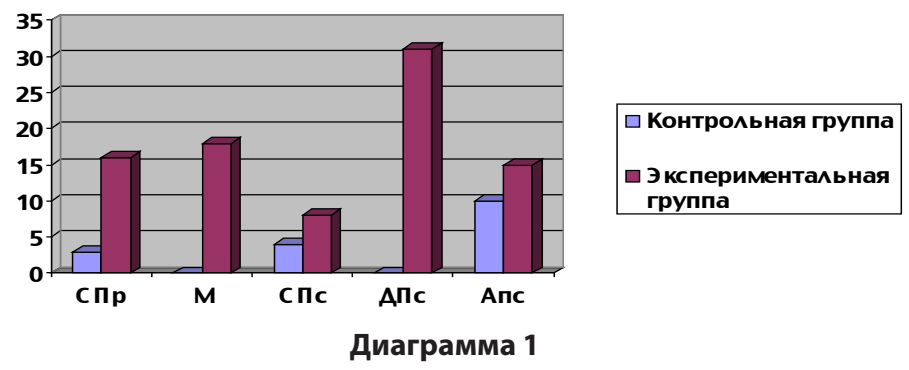


Учитывая доверительную вероятность результатов педагогического эксперимента (>5\%), можно утверждать, что статистически значимыми являются данные по специальной и профессиональной, методической и дифференциальнопсихологической компетентности работников образования. Увеличение методической и аутопсихологической компетентности участников экспериментальной и контрольной групп отличаются по данным сравнительного расхождения медиан, но статистически значимым признаны быть не могут.

Наиболее значимым результатом проведенного исследования является увеличение дифференциально-психологической компетентности в области оценивания мотивов и способностей учащихся.

С точки зрения компетентностного подхода к организации процесса обучения рост потенциальных возможностей учащихся является важнейшим показателем продуктивности учебного процесса.

Интегральный показатель развития профессиональной педагогической компетентности работников образования, зафиксированный на основе результатов проведенного педагогического эксперимента, можно вычислить с учетом весовых коэффициентов, характеризующих значимость каждого критериального показателя.

Интегральное значение сравнительного расхождения медиан экспериментальной и контрольной групп вычисляется по формуле, отражающей факторные веса каждого из компонентов профкомпетентности, полученные в ходе предварительной экспертизы:

$0,21 \times 13 \%+0,19 \times 18 \%+0,17 \times 4 \%+0,20 \times 31 \%+0,23 \times 5 \%=14,8 \%$.

Полученное значение является не только статистически значимым, но и демонстрирует достоверность и непротиворечивость выдвинутой гипотезы и разработанной теоретической модели исследования.

\section{Литература}

1. Сафонцев С.А., Шамильян О.И. Квалиметрический анализ процедур педагогического диагностирования // Гуманитарные и социально-экономические науки. 2006. № 5. С. 212-215.

2. Сафонцев С.А., Попов С.В., Сафонцева Н.Ю. Квалиметрические измерения в процессе мониторинга структуры и содержания образовательных программ // Стандарты и мониторинг в образовании. 2005. № 4. С. 20-23. 